\title{
Seasonal Variability in Chemical and Microbiological Status of Bottom Sediments in Lake Rusalka at Removal of Cyanobacterial Blooms from its Surface
}

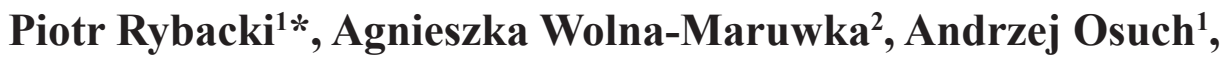 \\ Zenon Grześ ${ }^{1}$, Alicja Niewiadomska ${ }^{2}$ \\ 'Institute of Biosystem Engineering, Poznań University of Life Sciences, Poznań, Poland \\ ${ }^{2}$ Department of General and Environmental Microbiology, Poznań University of Life Sciences, Poznań, Poland
}

Received: 30 November 2018

Accepted: 14 April 2019

\begin{abstract}
The aim of this study was to collect data on the variability of dissolved oxygen content, $\mathrm{pH}$ and conductivity in waters of Lake Rusałka and the microbiological status of its bottom sediments following mechanical removal of the cyanobacterial blanket. Results indicate that mechanical removal of the bloom blanket from the lake surface accelerates oxygenation of its waters and growth of aerobic bacteria, mineralizing the bottom sediments and reducing $\mathrm{pH}$.
\end{abstract}

Keywords: cyanobacteria, lake reclamation, microbiological status

\section{Introduction}

Cyanobacteria are the oldest phytoplankton worldwide. They form harmful algal blooms observed as dense blankets in freshwater and marine ecosystems. Observations and research results suggest that eutrophication and climate change are processes that may promote their expansion and further spread [28].

The formation of cyanobacterial blooms and the resulting dense blankets prevent the penetration of light into deeper water layers, resulting in changes in the flora in water bodies, depletion of vegetation, development

*e-mail: piotr.rybacki@up.poznan.pl of anaerobic conditions and the appearance of toxins constituting a health hazard for humans and animals [12, 4-7, 8-9, 11-12, 14-15, 17, 21, 24, 27, 29-30, 33-35, 3741]. Due to the gas vacuoles in their cells, cyanobacteria are capable of changing their specific gravity, thus facilitating vertical movement and regulation of the depth at which they are submerged. This in turn promotes more efficient utilisation of light and oxygen dissolved in water. At high insolation the vacuoles reduce the amount of gas and as a result blooms descend, while at a deficit of light the vacuoles fill with gas and the cyanobacteria cells float immediately below the water surface in order to utilise the greatest possible amounts of solar energy. The capacity of cyanobacteria to utilise light promotes their proliferation, as they propagate only vegetatively by simple cell division $[16$, 31, 34, 36]. 
As reported by Gao and Cornwell (2014) [8] and O'Neil et al. (2012) [28], certain cyanobacteria species are capable of fixing $\mathrm{N}_{2}$, which results in additional amounts of nitrogen being introduced to lake waters and disturbs the food web equilibrium in aquatic ecosystems. Moreover, Glibert et al. (2011) [10] claimed that large amounts of biomass in the cyanobacteria blanket may have biogeochemical consequences for the nutrient cycle, elevation of $\mathrm{pH}$ and release of dissolved oxygen as well as supplementation of bottom sediments with extra organic matter due to sedimentation of dead cells.

In all environments, including aquatic ones, we observe a natural self-purification process in which next to physical factors a key role is played by autochthonous microorganisms as well as higher organisms. In bodies of standing water, in which due to stagnation of waters the organic matter sinks to the bottom, the self-purification process takes place to a considerable degree in bottom sediments, rich in various microbial populations. In this environment abundant in organic matter, aerobic conditions are found in its upper layers, while in lower layers anaerobic conditions develop, which differentiates the microflora into aerobic and anaerobic. Aerobic bacteria inhabiting bottom sediments include nitrifying, ammonifying and cellulolytic bacteria, while in the anaerobic layer proteolytic, denitrifying, cellulolytic and methanogenic bacteria predominate along with sulphatereducing and purple non-sulphur bacteria $[3,20,22-23$, 25].

Under aerobic conditions the organic matter (cellulose, starch, lignins, proteins, fats, etc.) is mineralised with the participation of bacteria to watersoluble phosphorus, nitrogen and sulphur ions. In turn, in the anaerobic zone toxic gases are released, such as ammonia, hydrogen sulfide and methane [18].

At a considerable influx of organic matter to bottom sediments aerobic bacteria may develop rapidly, leading to an increased oxygen demand, which as a consequence results in the generation of anaerobic conditions, sediment putrefaction, blooms of cyanobacteria and filamentous algae, as well as proliferation of other organisms typical of degraded water bodies [18].

\section{Aim and Scope of the Study}

The aim of the study was to assess the population of aerobic and anaerobic bacteria and determine dehydrogenase activity in bottom sediments sampled at different seasons of the year at four sampling points and from various depths of Lake Rusałka at the mechanical removal of cyanobacteria bloom blankets.

Additional chemical analysis of water from Lake Rusałka was conducted to determine its oxygen saturation, $\mathrm{pH}$ and conductivity at bottom sediment sampling points at various depths in three time intervals after the removal of cyanobacteria blankets. The results were analysed in order to confirm or refute the hypothesis that the removal of cyanobacteria bloom blankets accelerates lake reclamation thanks to increased oxygenation - particularly of deeper lake zones and growth of aerobic microorganisms as well as greater dehydrogenase activity.

\section{Material and Methods}

\section{Study Site}

Analyses of effectiveness of cyanobacteria blanket removal were conducted in the period of 10-15.07.2017 on Lake Rusałka, located in the northeastern part of the city of Poznan (Fig. 1). The lake is a dam reservoir created by damming the Bogdanka River and flooding of a section of its valley. The main causes for lake pollution include recreational activities, rainfall sewage and the location of the reservoir in an urbanised area.

Sampling points 1 to 4 were established in the sites where the cyanobacteria blanket was the thickest.

Efficiency of Lake Rusałka cleaning from the cyanobacteria blanket was assessed based on microbiological and enzymatic analyses, as well as the volume of collected green matter, water $\mathrm{pH}$ and contents of dissolved oxygen and depth of $1 \mathrm{~m}$ and $2 \mathrm{~m}$ in the designated points.

Bottom sediment samples for microbiological and biochemical analyses were collected from the established sampling points (Fig. 1) from the following depths:

- 1 sampling point - depth of approx. $1.2 \mathrm{~m}$,

- 2 sampling point - depth of approx. $2.4 \mathrm{~m}$,

- sampling point - depth of approx. $2.3 \mathrm{~m}$,

- sampling point - depth of approx. $3.0 \mathrm{~m}$.

\section{Device Designed to Remove Cyanobacteria Blankets}

In 2015 works were initiated at the Institute of Biosystem Engineering at the Poznan University of Life Sciences to develop a design and construct a prototype floating device for the removal of cyanobacteria blankets from the surface of water bodies. The schematic design of the device is given in Fig. 2.

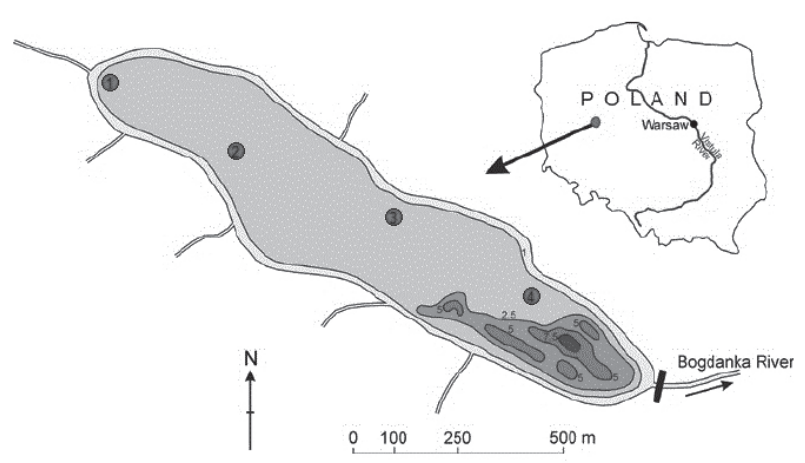

Fig. 1. Map of Lake Rusałka with designated water sampling points. 
The working element of the designed and constructed device consisted of a perforated belt (1) spread over two drums. The upper drum (9) is driven through a toothed gear with a totally enclosed direct current electric motor (5) of $480 \mathrm{~W}$, with controlled rotational speed. The source of current is a 100 Ah gel battery. The lower drum (8) is designed to be placed below the water surface and it is used to regulate the tension of the perforated belt. The conveyor belt (1) driven by the upper drum (9) and stretched by the lower drum (8) is moved with the controlled speed of $0.5-1 \mathrm{~m} \cdot \mathrm{s}^{-1}$. Below the perforated conveyor belt (1) and the lower drum (8) a chute is mounted (2). A periodically emptied cyanobacteria collector tank (4) is mounted under the upper conveyor drum (9). In the back section of the conveyor under the upper drum (9) a bar scrapping the belt (3) is placed to remove attached cyanobacteria layers. The described design is mounted on a floating frame composed of two cylindrical, horizontally arranged buoys of $5 \mathrm{~m}$ in length, connected with a steel structure with a seat for the operator. A combustion engine is installed in the back part of the device.

In the structural design of the floating device the perforated belt scoops the cyanobacteria blanket, predrains it and transports it to the collector tank. Tank walls have openings facilitating further drainage of water and thus reducing the mass of collected cyanobacteria. The perforated belt is scraped clean with the bar, which prevents it from being excessively covered with the sticking algal mass. In order to increase the working width of the presented device and to increase the thickness of the collected cyanobacteria blanket guide, bars are placed in the front part of the device. The tank containing the collected material is periodically emptied at the shore of the water body with the use of a screw conveyor.
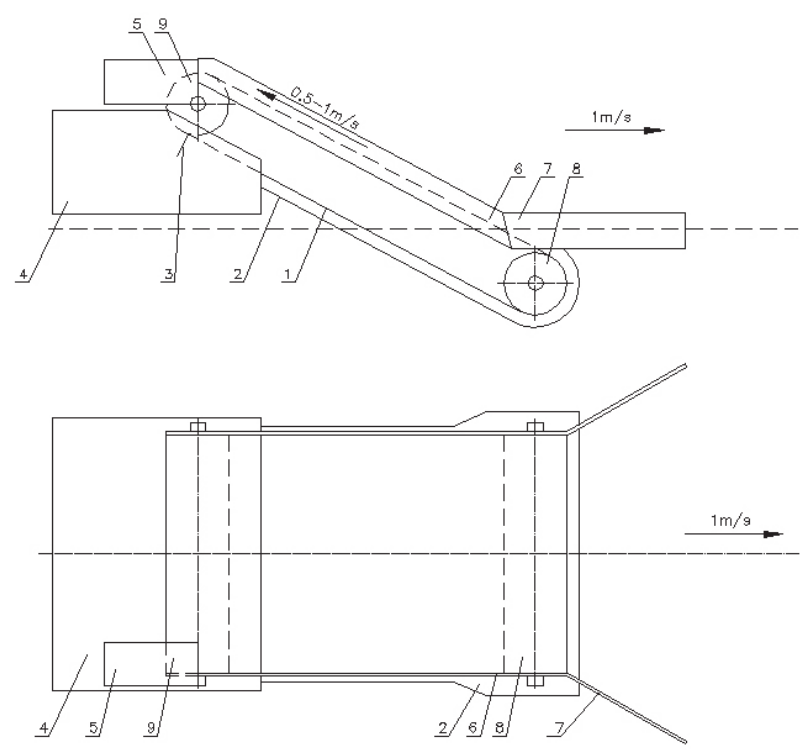

Fig. 2. Schematic design of the device for removing cyanobacteria blooms from the surface of water bodies.
Measuring Water Parameters, and Microbiological and Enzymatic Analyses of the Lake Bottom

\section{Sediments}

$\mathrm{pH}$, the amount of dissolved oxygen and its conductivity were measured using a process sensor for dissolved oxygen probe and a multiparameter Multi 340i apparatus by WTW.

Additionally, bacterial counts were determined along with their activity in order to identify the direction of biochemical changes taking place in Lake Rusałka bottom sediments. Metabolic activity of microorganisms and their general condition are established based on the assays of certain enzymes. In this respect dehydrogenases secreted by metabolically active microorganisms are particularly useful [42]. This results from a study by Niewiadomska et al. (2016) [26], in which dehydrogenase activity in the environment shows a positive dependence on the microbial counts and biomass; additionally, on this basis conclusions may be inferred on the content of organic substances in the substrate.

Enzymatic analyses conducted in this study consisted in the determination of dehydrogenase activity in the collected sediment samples using spectrophotometry. The level of dehydrogenase activity (DHA) was determined using 1\% TTC (tetrazolium chloride) as a substrate, following $24 \mathrm{~h}$ incubation at $30^{\circ} \mathrm{C}$ at a wavelength of $485 \mathrm{~nm}$. Enzyme activity was expressed in $\mu \mathrm{mol} \mathrm{TPF} \cdot \mathrm{g}^{-1} \mathrm{DM}$ of sediment $24 \mathrm{~h}^{-1}$. Microbiological analyses at the four successive dates of the experiment (I-June, II-July, III-August, IV-October) were conducted based on the method of serial dilutions. The analyses using the selective agar standard by Merck determined counts of colony forming units (CFU) of heterotrophic aerobic (AeB) and anaerobic bacteria (AnB). Counts of both bacterial populations were recorded after $24 \mathrm{~h}$ incubation at $35^{\circ} \mathrm{C}$. Anaerobic conditions under which Petri dishes were incubated were maintained using the Anaerocult anaerobic incubation system (Merck).

\section{Statistical Analysis}

Statistical analyses were performed in the Statistica 12.0 program. In order to verify the significance of changes in the counts and activity of investigated microorganisms depending on the experimental variant and the date of analysis, a two-way analysis of variance and Tukey's test were applied.

Data used for statistical analyses are represented as means of five replications. Letters a, b, c, d, e, and $f$ are homogenous groups according to Tuckey's test, where different letters denote statistical differences at level $\mathrm{p}=0.05 ; \mathrm{n}=5$.

Principal component analysis (PCA) was used to determine the type of dependencies between the microbiological parameters and dehydrogenase activity in the tested sediment samples at successive dates of analyses. 
Table 1. Volume $\left[\mathrm{m}^{3}\right]$ of cyanobacteria harvested from the lake surface.

\begin{tabular}{|c|c|c|c|c|c|c|}
\hline Date & $10 . \mathrm{VII}$ & $11 . \mathrm{VII}$ & $12 . \mathrm{VII}$ & $13 . \mathrm{VII}$ & $14 . \mathrm{VII}$ & $15 . \mathrm{VII}$ \\
\hline $\begin{array}{c}\text { Volume of harvested cyanobacteria } \\
{\left[\mathrm{m}^{3}\right]}\end{array}$ & 1.50 & 1.45 & 1.30 & 1.25 & 1.00 & 0.70 \\
\hline
\end{tabular}

\section{Results and Discussion}

As shown in Table 1, on the first day of tests $1.50 \mathrm{~m}^{3}$ cyanobacteria were collected from the lake surface. On each successive day the volume of collected green matter was decreasing and on the last day (15.07) $0.70 \mathrm{~m}^{3}$ were collected. This shows a reduction in the cyanobacteria blanket thickness. In the course of six days of analyses a total volume of $7.20 \mathrm{~m}^{3}$ was removed from the surface of Lake Rusałka. In their study, Paerl et al. (2016) [30] presented similar methods of removing cyanobacteria, consisting in the sucking out of the bloom blanket or the establishment of barriers at the locations where it was accumulating. However, those authors did not report the weight or volume of the collected green matter and this prevented any precise determination of the amount of biogens removed from the water bodies.

Table 2 presents mean dissolved oxygen contents in the waters of Lake Rusałka depending on the depth and date of sampling. In all the sampling points a significant reduction was observed in the amount of dissolved oxygen. While on the surface it ranged from 5.45 to $5.76 \mathrm{mg} \cdot \mathrm{dm}^{-3}$, at a depth of $2 \mathrm{~m}$ this content ranged from 2.12 to $2.33 \mathrm{mg} \cdot \mathrm{dm}^{-3}$.

It may be observed from the recorded data that after 31 days from the tests of the floating device and the removal of the cyanobacteria blanket the mean dissolved

Table 2. Mean dissolved oxygen content $\left[\mathrm{mg} \cdot \mathrm{dm}^{-3}\right]$ in waters at sampling points in the lake depending on the date of measurement.

\begin{tabular}{|c|c|c|c|c|}
\hline Sampling points & 1 & 2 & 3 & 4 \\
\hline \multicolumn{6}{|c|}{15.07 .2017} \\
\hline $0 \mathrm{~m}$ & 5.76 & 5.72 & 5.66 & 5.45 \\
\hline $1 \mathrm{~m}$ & 4.20 & 4.22 & 4.23 & 4.23 \\
\hline $2 \mathrm{~m}$ & 2.12 & 2.13 & 2.25 & 2.33 \\
\hline \multicolumn{6}{|c|}{15.08 .2017} \\
\hline $0 \mathrm{~m}$ & 6.01 & 6.05 & 5.95 & 6.11 \\
\hline $1 \mathrm{~m}$ & 5.97 & 5.99 & 6.03 & 5.91 \\
\hline $2 \mathrm{~m}$ & 5.59 & 5.57 & 5.45 & 5.61 \\
\hline \multicolumn{6}{|c|}{15.09 .2017} \\
\hline $0 \mathrm{~m}$ & 6.20 & 6.22 & 6.23 & 6.15 \\
\hline $1 \mathrm{~m}$ & 6.10 & 6.14 & 6.15 & 6.06 \\
\hline $2 \mathrm{~m}$ & 5.63 & 5.61 & 5.55 & 5.53 \\
\hline
\end{tabular}

oxygen content in water increased. The greatest increase in the dissolved oxygen level was recorded at a depth of $2 \mathrm{~m}$, ranging at the established sampling points from 5.45 to $5.61 \mathrm{mg} \cdot \mathrm{dm}^{-3}$ (Table 2).

After the next 31 days following the removal of the cyanobacteria blanket a further increase in dissolved oxygen contents in the lake waters was observed; however, in this case it was much smaller.

From the point of view of the biological status of the lake, the lake water reaction plays a considerable role. A high $\mathrm{pH}$ value may indicate considerable contents of noxious biogens, e.g., phosphorus compounds, which at a limited supply of oxygen may cause the growth of harmful organisms and disturbance of biological equilibrium. Phosphorus and nitrogen were not determined, which had to be taken into account in further studies.

This results from the data given in Table 3 that on the first day after cyanobacteria harvest the mean $\mathrm{pH}$ value at the established sampling points at a depth of $2 \mathrm{~m}$ was 8.14. Water analyses conducted at successive pre-determined periods showed a significant decrease in $\mathrm{pH}$ at that depth, i.e., on 15.08.2017 it was to the mean value of 6.25 , while on 15.09.2017 it was to 6.15 , respectively.

When analysing water conductivity at the established sampling points we may observe its slight increase with depth, while at the same time it decreased with an increase in oxygen saturation of lake waters (Table 4).

The quantitative and qualitative composition of microflora in bottom sediments varies and may depend both on the type of the water body and on the sampling site and depth, as evidenced by results presented in Figs 3 and 4.

Greater microbial counts in bottom sediments of water bodies in comparison to those recorded in water are connected with the presence of organic residue of plant and animal origin settling on the bottom. This results from a study by Miskin et al. (1998) [23] in which the greatest count of cultured bacteria is

Table 3. Mean $\mathrm{pH}$ values of the water depending on the depth of the lake.

\begin{tabular}{|c|c|c|c|}
\hline Depth & Measurement \\
date & 15.07 .2017 & 15.08 .2017 & 15.09 .2017 \\
\hline $0 \mathrm{~m}$ & 8.15 & 5.95 & 5.64 \\
\hline $1 \mathrm{~m}$ & 8.15 & 6.13 & 5.95 \\
\hline $2 \mathrm{~m}$ & 8.14 & 6.25 & 6.15 \\
\hline
\end{tabular}


Table 4 . Mean conductivity $\left[\mu \mathrm{S} \cdot \mathrm{cm}^{-1}\right]$ of water depending on the depth of the lake.

\begin{tabular}{|c|c|c|c|}
\hline Depth & 15.07.2017 & 15.08 .2017 & 15.09 .2017 \\
\hline $0 \mathrm{~m}$ & 657 & 656 & 645 \\
\hline $1 \mathrm{~m}$ & 671 & 659 & 651 \\
\hline $2 \mathrm{~m}$ & 688 & 675 & 665 \\
\hline
\end{tabular}

found in the surface layers of sediments (up to $10^{7} \mathrm{CFU}$ per $1 \mathrm{~g}$ DM of sediment), while at a depth of $3 \mathrm{~m}$ it was $10^{1}-10^{2}$ CFU per $1 \mathrm{~g} \mathrm{DM}$ sediment. Among the isolated species, the authors reported the presence of both Gram-negative and Gram-positive species, while in the deeper sediment layers sporulating bacteria predominated.

Microbiological analysis of the bottom sediment conducted in this study showed that both the date of the analysis and the depth from which samples were collected from the bottom sediment had a statistically significant effect on the population size of aerobic bacteria (Fig. 5). We found that these bacteria were present in sediments sampled from depths of 1, 2, and even $3 \mathrm{~m}$, maintaining their counts at a constant level of $10^{3} \mathrm{CFU} \mathrm{g}^{-1} \mathrm{DM}$ sediment.

At sampling date 1 the highest counts of bacteria were recorded at sampling point 2 , in which sediment samples were collected from a depth of $2.4 \mathrm{~m}$. At the next date of analyses the AeB counts in the analysed objects did not differ statistically significantly and remained on a low level of $6.29-30.36 \cdot 10^{3} \mathrm{CFU} \mathrm{g}^{-1} \mathrm{DM}$ sediment.

Samples of sediments collected in August (date III) showed an increase in the proliferation of the discussed microorganisms, most probably connected with the sediment being enriched with phytoplankton dying after spring blooms or with an increase in air temperature, and thus a resulting increase in water temperature. Also Lindström et al. (2005) [19], after testing waters in 15 lakes of northern Europe in the months of May-June, showed that water temperature (next to $\mathrm{pH}$ and retention time) is a major factor modifying the quantitative and qualitative composition of lacustrine microflora.

A statistically significant increase in $A e B$ counts in the discussed date was observed in the sediment collected at sampling points 1 and 4 . Despite the difference in sampling depth of $1.8 \mathrm{~m}$, counts of bacteria were comparable, amounting to $100 \cdot 10^{3} \mathrm{CFU} \mathrm{g}^{-1} \mathrm{DM}$ sediment.

At the last date of analysis (IV) at all the sampling points, a decrease was observed in the proliferation of the discussed microorganisms, most probably resulting from a reduction in temperature in October or a decrease in oxygen content in the sediment, which was confirmed by the increase in the counts of anaerobic bacteria (Fig. 3) at that time.

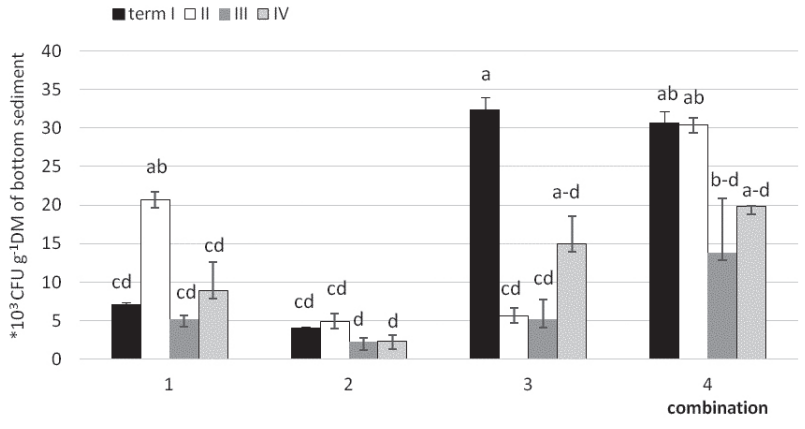

Fig. 3. Anaerobic bacteria (a, b, c, d, e, and f are homogenous groups according to Tukey's).

Microbiological analysis of sediment samples collected from the four sampling points showed similarly to the case of aerobic bacteria. At most dates of analyses the greatest counts of anaerobic bacteria and the highest dehydrogenase activity (Fig. 4) were found in the bottom sediment collected from a depth of $3 \mathrm{~m}$.

The level of dehydrogenase activity (DHA) was determined according to Camiña et al. (1998)

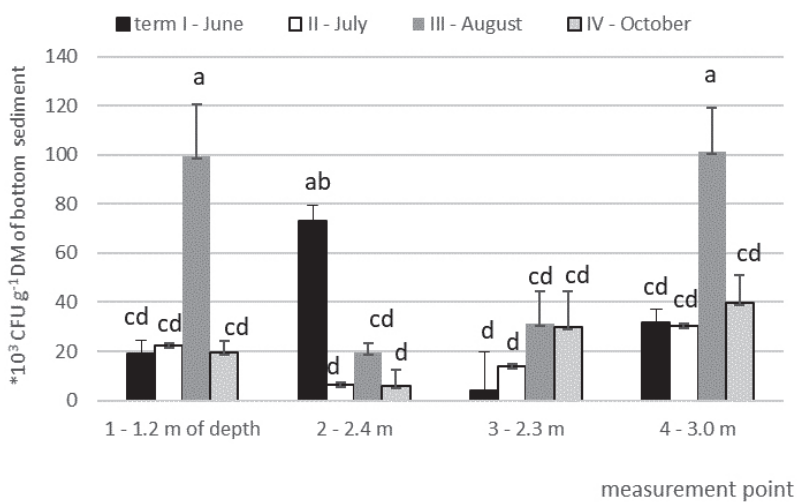

Fig. 4. Total counts of aerobic bacteria in bottom sediments ( $a, b$, c, d, e, and f are homogenous groups according to Tukey's); note that means followed by the same letters do not differ significantly at $\mathrm{p}=0.05$.

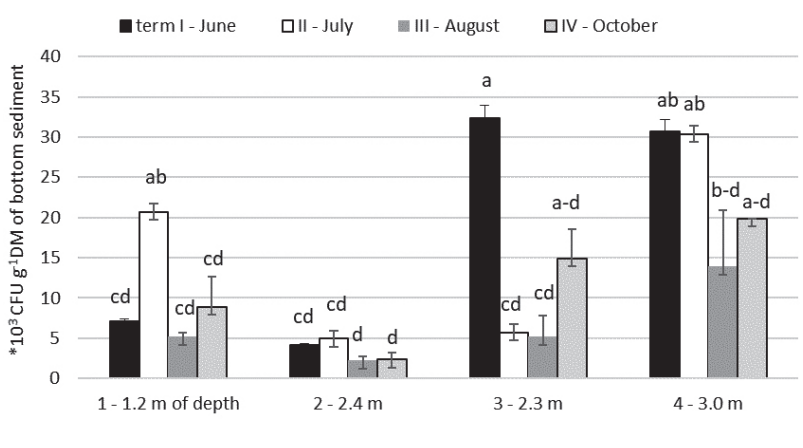

Fig. 5. Total counts of anaerobic bacteria in bottom sediments (a, $\mathrm{b}, \mathrm{c}, \mathrm{d}$, e, and $\mathrm{f}$ are homogenous groups according to Tukey's); note that means followed by the same letters do not differ significantly at $\mathrm{p}=0.05$. 


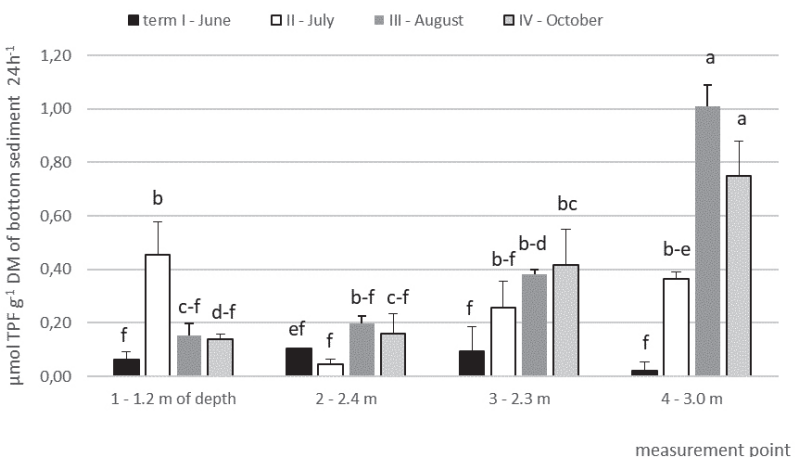

Fig. 6. Dehydrogenase activity in bottom sediments (a, b, c, d, $\mathrm{e}$, and $\mathrm{f}$ are homogenous groups according to Tukey's); not that means followed by the same letters do not differ significantly at $\mathrm{p}=0.05$.

[2]. Samples ( $1 \mathrm{~g}$ ) were incubated for $24 \mathrm{~h}$ with 2,3,5-triphenyltetrazolium chloride (TTC) at $30^{\circ} \mathrm{C}$, $\mathrm{pH}$ 7.4. The produced triphenylformazan (TPF) was extracted with $96 \%$ ethanol and measured spectrophotometrically at $485 \mathrm{~nm}$. Enzyme activity was expressed in $\mu \mathrm{mol}$ TPF. $\mathrm{g}^{-1} \mathrm{DM}$ of sediment $24 \mathrm{~h}^{-1}$

High AnB counts and their activity in the discussed object resulted most probably from the large amounts of organic matter deposited by tributaries. It also results from a study by Polyak et al. (2017) [32], in which the DHA level is dependent on organic matter content. When analysing enzymatic activity of surface sediments in the Gulf of Finland, those authors showed that the activity of dehydrogenases, being solely intracellular enzymes, shows the intensity of respiratory metabolism of the microbial population, and as a result it is treated as a measure of organic matter content in a given environment.

In turn, Jaiswal and Pandey (2018) [13], when analysing the enzymatic activity of river sediment from the Ganges in India, stated that the dependencies between organic matter content in the water and sediment collected at nine sampling points and the level of their enzymatic activity varied, and that it might be a tool in the monitoring of water quality.

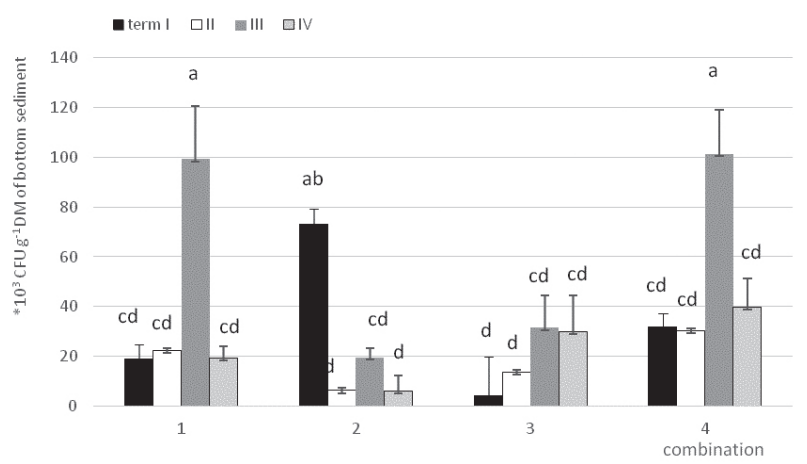

Fig. 7. Aerobic bacteria (a, b, c, d, e, and $\mathrm{f}$ are homogenous groups according to Tukey's); note that means followed by the same letters do not differ significantly at $\mathrm{p}=0,05$.

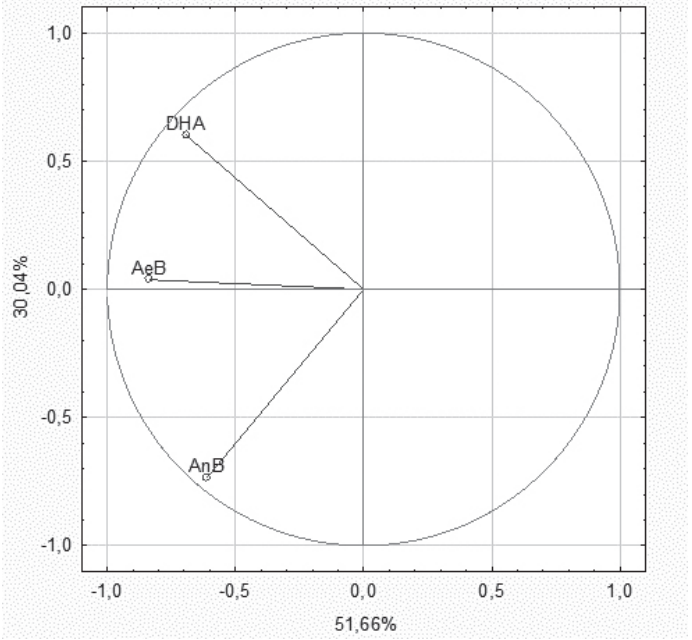

Fig. 8. Dependences between the number and activity of bacteria in the experimental sediment combinations at consecutive dates of analyses (PCA); DHA- dehydrogenase activity, AeB- aerobic bacteria, AnB- anaerobic bacteria.

Based on the results recorded in this study, we also showed that the counts of anaerobic bacteria and DHA were statistically significantly modified both by the depth from which sediment samples were collected and by the dates of analyses.

Depending on the type of object, anaerobic bacteria showed the highest population size at dates I or II, while their count was lowest at date III, at the simultaneous increase in the proliferation of aerobic bacteria and the level of dehydrogenase activity (Fig. 7).

In order to show the type of dependence between the identified groups of microorganisms and DHA, we applied PCA (Fig. 8), which showed regularities between independent variables by determining the components being a linear combination of the analysed variables. Moreover, it indicated these original variables, which constitute the reference system for the other variables. It needs to be stressed here that in the new system of coordinates a large proportion of variability was explained (81.7\%).

The above-mentioned statistical analysis confirmed a positive correlation between the count of aerobic bacteria and dehydrogenase activity, as well as a lack of any dependency between enzymatic activity and the count of anaerobic bacteria in the bottom sediments collected from various sampling points.

Moreover, despite differences in the AeB and AnB counts at the consecutive dates of analyses, PCA showed a positive dependence between proliferation of these microorganisms determined at the four sampling points.

A review of literature on the subject clearly showed a limited number of scientific publications in Polish literature concerning the effect of sediment sampling depth and the season of the year on the microbiological status and the level of enzymatic activity of bottom sediment from a eutrophic lake. For this reason this 
study made it possible to show the rate of changes in organic matter in bottom sediment depending on sampling depth and the season of the year.

\section{Conclusions}

On the basis of the conducted study and the analysis of the results, the following conclusions may be drawn:

1. Irrespective of the depth from which samples of bottom sediment were collected, the counts of aerobic and anaerobic bacteria remained at $103 \mathrm{CFU}$ per $1 \mathrm{~g}$ DM of sediment.

2. The greatest population size and activity of the analysed microorganisms in sediment samples collected from various depths were recorded in June or August.

3. The largest amounts of degradable organic matter were found in sediment sampled from a depth of 3 $\mathrm{m}$, as evidenced by the greatest counts of aerobic and anaerobic bacteria and the level of dehydrogenase activity (sampling point 4).

4. A higher level of metabolic activity was found for aerobic bacteria, which was confirmed by PCA showing a close positive dependence between their counts and the level of dehydrogenase activity.

5. Mechanical removal of the dense cyanobacteria blanket from the lake surface results in more intensive water oxygenation, a reduction of water conductivity and $\mathrm{pH}$, while it prevents the enrichment of bottom sediments with additional amounts of organic matter - thanks to which the processes of lake reclamation may be accelerated.

\section{Conflict of Interest}

The authors declare no conflict of interest.

\section{References}

1. ABBAS M., ADIL M., EHTISHAM-UL-HAQUE S., MUNIR B., YAMEEN M., GHAFFAR A., ABBAS SHAR G., TAHIR A. M., IQBAL M. Vibrio fischeri bioluminescence inhibition assay for ecotoxicity assessment: A review. Science of the Total Environment 626, 1295, 2018.

2. CAMIÑA F., TRASAR-CEPEDA C., GIL-SOTRES F., LEIRÓS C. Measurement of dehydrogenase activity in acid soils rich in organic matter. Soil Biology and Biochemistry, 30 (8-9), 1005, 1998.

3. CHEN J., WANG P.F., WANG C., LIU J.J., GAO H., WANG X. Spatial distribution and diversity of organohalide-respiring bacteria and their relationships with polybrominated diphenyl ether concentration in Taihu Lake sediments. Environmental Pollution, 232, 200, 2018.

4. CIRE S., BALLOT A. A review of the phylogeny, ecology and toxin production of bloom-forming Aphanizomenon spp. and related species within the Nostocales (cyanobacteria). Harmful Algae 54, 21, 2016.
5. DAVIS T.W., BERRY D.L., BOYER G.L. GOBLER C.J. The effects of temperature and nutrients on the growth and dynamics of toxic and non-toxic strains of Microcystisduring cyanobacteria blooms. Harmful Algae, 8, 715, 2009.

6. ELLIOTT J.A. The seasonal sensitivity of cyanobacteria and other phytoplankton to changes in flushing rate and water temperature. Global Change Biology, 16, 864, 2010.

7. FALCONER I.R. An Overview of problems caused by toxic blue-green algae (cyanobacteria) in drinking and recreational water. Environmental Toxicology. 14 (1), 5, 1999.

8. GAO Y., CORNWELL J.C. Influence of cyanobacteria blooms on sediment biogeochemistry and nutrient fluxes. Limnology and Oceanography 59 (3), 959, 2014.

9. GAŁCZYŃSKI Ł., OCIEPA A. Toxins produced by Cyanoprokaryota. Ecological chemistry and engineering. 15 (1), 69, 2008.

10. GLIBERT P.M., FULLERTON D., BURKHOLDER J. M., CORNWELL J.C., KANA T. M. Ecological stoichiometry, biogeochemical cycling, invasive species, and aquatic food webs: San Francisco estuary and comparative systems. Rev. Fish. Sci. 19, 1, 2011.

11. GRIESE M., LANGE CH., SOPPA J. Ploidy in cyanobacteria. Microbiology Letters 323 (2), 124, 2011.

12. HUSSAIN F., SHAH S.Z., ZHOUA W., IQBAL M. Microalgae screening under $\mathrm{CO}_{2}$ stress: Growth and micronutrients removal efficiency. Journal of Photochemistry \& Photobiology, B: Biology 170, 91, 2017.

13. JAISWAL D., PANDEY J. Impact of heavy metal on activity of some microbial enzymes in the riverbed sediments: Ecotoxicological implications in the Ganga River (India). Ecotoxicology and environmental safety, 150, 104, 2018

14. JIANG X., XIE J., XU Y., ZHONG W., ZHU X., ZHU CH. Increasing dominance of small zooplankton with toxic cyanobacteria. Freshwater Biology 62 (2), 429, 2017.

15. KARDINAAL W.E.A., TONK L., JANSE I., HOL S., SLOT P., HUISMAN J. ET AL. Competition for light between toxic and nontoxic strains of the harmful cyanobacterium Microcystis. Applied and Environmental Microbiology, 73, $2939,2007$.

16. KOSTEN S., HUSZAR V., BECARES E., COSTA L., VAN DONK E., HANSSON L.-A. ET AL. Warmer climate boosts cyanobacterial dominance in lakes. Global Change Biology, 18, 118, 2012.

17. LATIFI A., RUIZ M., ZHANG CH. Oxidative stress in cyanobacteria. Microbiology Reviews 33 (2), 258, 2009.

18. LIU Y., CONRAD R., YAO T., GLEIXNER G., CLAUS P. Change of methane production pathway with sediment depth in a lake on the Tibetan plateau. Palaeogeography, Palaeoclimatology, Palaeoecology, 474, 279, 2017.

19. LINDSTRÖM E.S., KAMST-VAN AGTERVELD M.P., ZWART G. Distribution of typical freshwater bacterial groups is associated with $\mathrm{pH}$, temperature, and lake water retention time. Applied and environmental microbiology, 71 (12), 8201, 2005.

20. LV B., CUI Y., TIAN W., FENG D. Composition and influencing factors of bacterial communities in ballast tank sediments: Implications for ballast water and sediment management. Marine environmental research, 132, 14, 2017.

21. IQBAL M. Vicia faba bioassay for environmental toxicity monitoring: Areview. Chemosphere 144, 785, 2016. 
22. MARTINEZ-CRUZ K., LEEWIS M.C., HERRIOTT I.C., SEPULVEDA-JAUREGUI A., ANTHONY K.W., THALASSO F., LEIGH M.B. Anaerobic oxidation of methane by aerobic methanotrophs in sub-Arctic lake sediments. Science of The Total Environment, 607, 23, 2017.

23. MISKIN I., RHODES G., LAWLOR K., SAUNDERS J.R., PICKUP R.W. Bacteria in post-glacial freshwater sediments. Microbiology, 144 (9), 2427, 1998.

24. MOLOT L.A., WATSON S.B., CREED I.F., TRICK C.G., MCCABE S.K., VERSCHOOR M.J., SORICHETTI R.J., POWE C., VENKITESWARAN J.J., SCHIFF S.L. A novel model for cyanobacteria bloom formation: the critical role of anoxia and ferrous iron. Freshwater Biology 59 (6), 1323, 2014.

25. NEALSON K.H. Sediment bacteria: who's there, what are they doing, and what's new?. Annual Review of Earth and Planetary Sciences, 25 (1), 403, 1997.

26. NIEWIADOMSKA A., GAJ R., PRZYBYŁ J., BUDKA A., MIODUSZEWSKA N., WOLNA-MARUWKA A. Analysis of Microbial Parameters of Soil in Different Tillage Systems Under Sugar Beets (Beta vulgaris L.). Polish Journal of Environmental Studies, 25 (5), 2016.

27. NOREEN M., SHAHID M., IQBAL M., NISAR J. Measurement of cytotoxicity and heavy metal load in drains water receiving textile effluents and drinking water in vicinity of drains. Measurement 109, 88, 2017.

28. O'NEIL J.M., DAVIS T.W., BURFORD M.A., GOBLER C.J. The rise of harmful cyanobacteria blooms: The potential roles of eutrophication and climate change. Harmful Algae 14, 313, 2012.

29. PAERL H.W., HALL N.S., CALANDRINO E.S. Controlling harmful cyanobacterial blooms in a world experiencing anthropogenic and climatic-induced change. Sci. Total Environ. 409, 1739, 2011.

30. PAERL H.W., GARDNER W.S., HAVENS K.E., JOYNER A.R., MCCARTHY M.J., NEWELL S.E., QIN B., SCOTT J.T. Mitigating cyanobacterial harmful algal blooms in aquatic ecosystems impacted by climate change and anthropogenic nutrients. Harmful Algae 54, 213, 2016.

31. PAPADIMITRIOU T., KAGALOU I., BACOPOULOS V., LEONARDOS I. Accumulation of microcystins in water and fish tissues: an estimation of risks associated with microcystins in most of the Greek lakes. Environmental Toxicology, 25, 418, 2010.

32. POLYAK Y., SHIGAEVA T., GUBELIT Y., BAKINA L., KUDRYAVTSEVA V., POLYAK M. Sediment microbial activity and its relation to environmental variables along the eastern Gulf of Finland coastline. Journal of Marine Systems, 171, 101, 2017.

33. POPE P.B., PATEL B.K.C. Metagenomic analysis of a freshwater toxic cyanobacteria bloom. Microbiology Ecology. 64 (1) 9, 2008.

34. ROMO S., SORIA J., FERNÁNDEZ F., OUAHID Y., BARÓN-SOLÁ A. Water residence time and the dynamics of toxic cyanobacteria. Freshwater Biology 58 (3), 513, 2013.

35. TANGO P.J., AND BUTLER W. Cyanotoxins in tidal waters of Chesapeake Bay. Northeast. Nat. 15, 403, 2008.

36. THOMPSON P.A., JAMESON I., BLACKBURN S.I. The influence of light quality on akinete formation and germination in the toxic cyanobacterium Anabaena circinalis. Harmful Algae 8, 504, 2009.

37. TONK L., BOSCH K., VISSER P.M., HUISMAN J. Salt tolerance of the harmful cyanobacterium Microcystis aeruginosa. Aquat. Microb. Ecol. 46, 117, 2007.

38. UKPAKA C.P. Empirical model approach for the evaluation of $\mathrm{pH}$ and conductivity on pollutant diffusion in soil environment. Chemistry International 2 (4), 267, 2016.

39. UKPAKA C.P., UKPAKA C. Characteristics of groundwater in Port-Harcourt local Government area. Chemistry International 2 (3), 136, 2016.

40. UKPAKA C.P. BTX Degradation: The concept of microbial integration. Chemistry International 3 (1), 8, 2017.

41. UKPAKA C.P., WAMI E.N. Degradation biokinetics of used and fresh lube oils in contaminated soil environment. Chemistry International 3 (4), 494, 2017.

42. WOLINSKA A., STEPNIEWSKA Z., SZYMANSKA E. Dehydrogenase activity of soil microorganisms and the total DNA level in soil of different use. Journal of Agricultural Science and Technology. B. 3, 613, 2013. 